\title{
Determination of the Levels of Anti-Thyroid- Stimulating Hormone Receptor Antibody with Thyroid Peroxidase Antibody in Omani Patients with Graves' Disease
}

\author{
Adel Alnaqdy ${ }^{\mathrm{a}}$ Masoud Al-Maskari ${ }^{\mathrm{b}}$ \\ Departments of ${ }^{\mathrm{a}}$ Microbiology and Immunology and ${ }^{\mathrm{b}}$ Medicine, College of Medicine and Health Sciences, \\ Sultan Qaboos University, Al-Khod, Sultanate of Oman
}

\section{Key Words}

Graves' disease - Anti-thyroid-stimulating hormone receptor antibody · Thyroid · Autoantibody · Thyroid peroxidase antibodies

\begin{abstract}
Objective: To determine the levels of anti-thyroid-stimulating hormone receptor antibody (TRAb) and thyroid peroxidase antibodies (TPO) in Omani patients with Graves' disease (GD). Subjects and Methods: ELISA was used to measure the levels of TRAb and TPO in sera of 111 patients with GD, 40 patients with systemic lupus erythematosus (SLE) and 50 healthy normal subjects. Seventy-eight GD patients received iodine-131 treatment while 33 newly diagnosed patients did not receive any treatment. Results: The levels of TRAb in the patients with GD, SLE and normal subjects were $7.249 \pm 0.623$, $1.04 \pm 0.179$ and $0.539 \pm 0.070$ units/liter, respectively. Elevated levels of TRAb were found in 75,5 and $2 \%$ of patients with GD, SLE and normal subjects, respectively. For anti-TPO antibodies, the levels were $713.331 \pm$ $97.905,85.575 \pm 34.936$ and $22.96 \pm 4.544 \mathrm{IU} / \mathrm{ml}$, for patients with GD, SLE and normal subjects, respectively. The elevated level of anti-TPO antibodies were found in 72,15 and $6 \%$ of patients with GD, SLE and normal subjects. Statistically significant differences in positive lev-
\end{abstract}

els of TRAb and anti-TPO antibodies were found in patients with GD as compared to SLE and normal subjects $(p<0.001)$. The treated GD patients had lower levels of TRAb than untreated, but no difference was detected in the levels of anti-TPO antibodies between the treated and not treated. Conclusion: High levels of TRAb and TPO were detected in Omani patients with GD. TRAb may be helpful in the diagnosis and monitoring the efficacy of iodine-131 treatment in GD patients.

Copyright $\subset 2005$ S. Karger AG, Basel

\section{Introduction}

Abnormal autoimmune reactions to thyroid-specific proteins, including the thyroid-stimulating hormone (TSH) receptor, thyroglobulin, and thyroid peroxidase (TPO), in autoimmune thyroid diseases such as Graves' disease (GD) have been the subject of interest by many investigators $[1,2]$. The TSH receptor plays an important role in the function and growth of thyroid cells [3]. GD is thought to result from the production of autoantibodies to the TSH receptor (TRAb). Binding of these autoantibodies to the TSH receptors causes stimulation of thyroid cells and overproduction of thyroid hormones, resulting in hyperthyroidism [4]. TRAb is a well-known marker for thyroid gland autoimmunity and thus may have predic-

\section{KARGER}

Fax +4161306 1234 E-Mail karger@karger.ch www.karger.com
(C) 2005 S. Karger AG, Basel

$1011-7571 / 05 / 0144-0209 \$ 22.00 / 0$

Accessible online at:

www.karger.com/mpp
Dr. A. Alnaqdy

College of Medicine and Health Sciences PO Box 35

Al-Khod 123 (Sultanate of Oman)

Tel. +968515147, Fax +968513419, E-Mail aalwan@squ.edu.om 
tive value in the recurrence of GD after treatment with antithyroid drugs [5]. This antibody has been reported to be present in more than $80 \%$ of GD patients and thus may activate thyroprotein receptors and produce clinical thyrotoxicosis [6].

Consequently, the measurement of TRAb could be valuable for the differential diagnosis of hyperthyroidism as well as for the follow-up of GD patients receiving antithyroid drugs, such as iodine-131 sodium iodide $\left({ }^{131} \mathrm{I}\right)$ or surgery. The presence of TRAb may also help in distinguishing GD from other causes of thyrotoxicosis such as factitious thyrotoxicosis and other causes of hyperthyroidism like subacute or postpartum thyroiditis and toxic nodular goiter.

The study of GD has been facilitated by the identification of dominant specific target antigens for TRAb and TPO antibodies [4, 7]. These antibodies are now routinely measured in suspected GD to confirm the diagnosis of autoimmune thyroid disease. Thus, the objective of this study was to determine the levels of TRAb and TPO antibodies in Omanis with GD, systemic lupus erythematosus (SLE) and normal subjects.

\section{Subjects and Methods}

\section{Subjects}

The study included 111 adult Omani subjects ( 75 females and 36 males) with a clinical diagnosis of GD (age range 16-66 years, average 32.4 years). Seventy-eight of them received ${ }^{131}$ I treatment while 33 newly diagnosed patients did not receive any treatment. A further 40 patients with SLE (as autoimmune nonthyroid controls) and 50 healthy control subjects were included in the study. GD, SLE patients and control subjects were matched in terms of age and sex. Sera from all the subjects were screened for the presence of TRAb and TPO antibodies.

\section{Measurement of TRAb}

Circulating levels of TRAb were measured with a commercial ELISA kit (Medizym T.R.A., Medipan Diagnostica, Germany) according to the manufacturer's instructions. Values of $>2$ units/1 were considered as positive as set by the manufacturer.

\section{Measurement of TPO}

An ELISA assay (Medizym anti-TPO, Medipan Diagnostica) was employed for the quantitative measurement of human TPO antibodies in serum. A standard ELISA technique was employed using buffers and reagents supplied with the kit. All procedures were performed according to manufacturers' instructions. TPO antibody values of $>30 \mathrm{IU} / \mathrm{ml}$ were considered as positive.

\section{Statistical Analysis}

Statistical analysis was performed using $\chi^{2}$ test from SPSS for windows program. A $p$ value $<0.05$ was considered as significant.

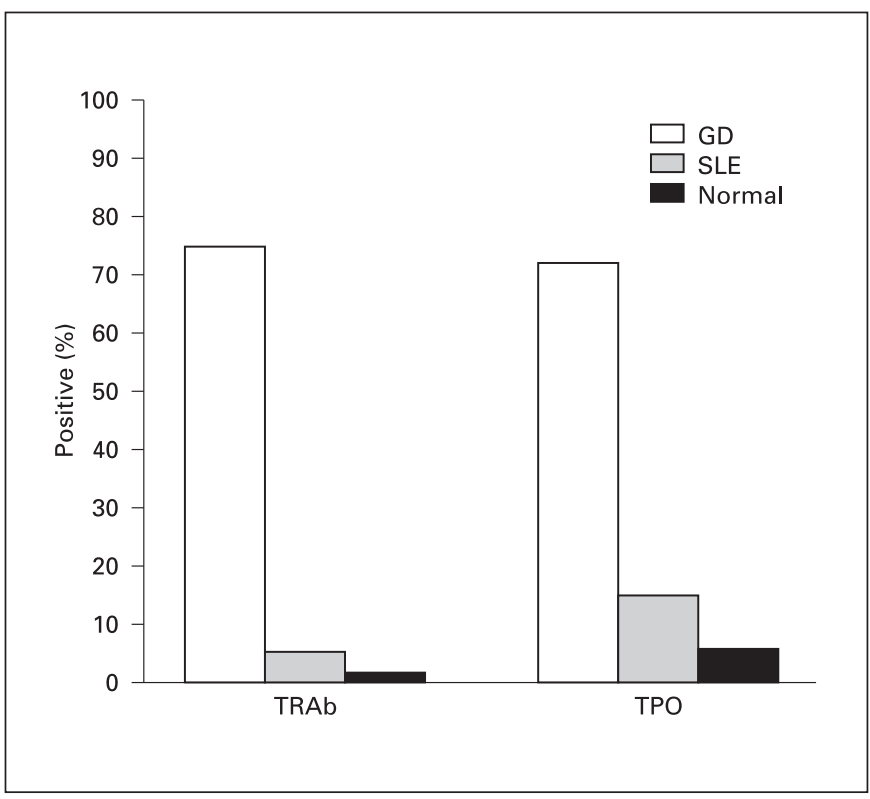

Fig. 1. Percentage of Omani patients with GD screened for serum antibodies to TRAb and TPO antibodies in comparison to those derived from normal controls and patients with SLE.

\section{Results}

Elevated TRAb levels were found in $75 \%$ of patients with GD (7.249 \pm 0.623 units/l; mean $\pm \mathrm{SE})$, in $5 \%$ of patients with SLE $(1.024 \pm 0.179$ units/l; mean \pm SE) and in $2 \%$ of normal subjects $(0.539 \pm 0.070$ units $/$; mean $\pm \mathrm{SE})$. As for anti-TPO antibodies, the values were found to be $72 \%$ of patients with GD (713.331 \pm $97.905 \mathrm{IU} / \mathrm{ml}$; mean $\pm \mathrm{SE}), 15 \%$ with SLE $(85.575 \pm$ $34.936 \mathrm{IU} / \mathrm{ml}$; mean $\pm \mathrm{SE}$ ) and $6 \%$ of normal subjects $(22.96 \pm 4.544 \mathrm{IU} / \mathrm{ml}$; mean $\pm \mathrm{SE})$ (fig. 1). Positive sera for both TRAb and TPO were significantly higher in GD patients as compared to SLE patients and normal subjects $(\mathrm{p}<0.0001)$. No difference was found between gender and age.

As shown in figure 2, GD patients receiving ${ }^{131}$ I treatment had a significantly lower level of TRAb than the nontreated patients $(\mathrm{p}<0.005)$. Positive levels were found in 42.5 and $88.5 \%$ of the treated and nontreated patients, respectively. No difference was observed between positive TPO values of the treated $(70 \%)$ and untreated $(75 \%)$ patients.

No correlation $(r=0.14 ; p=0.13)$ was found between the levels of TRAb and TPO antibody. 


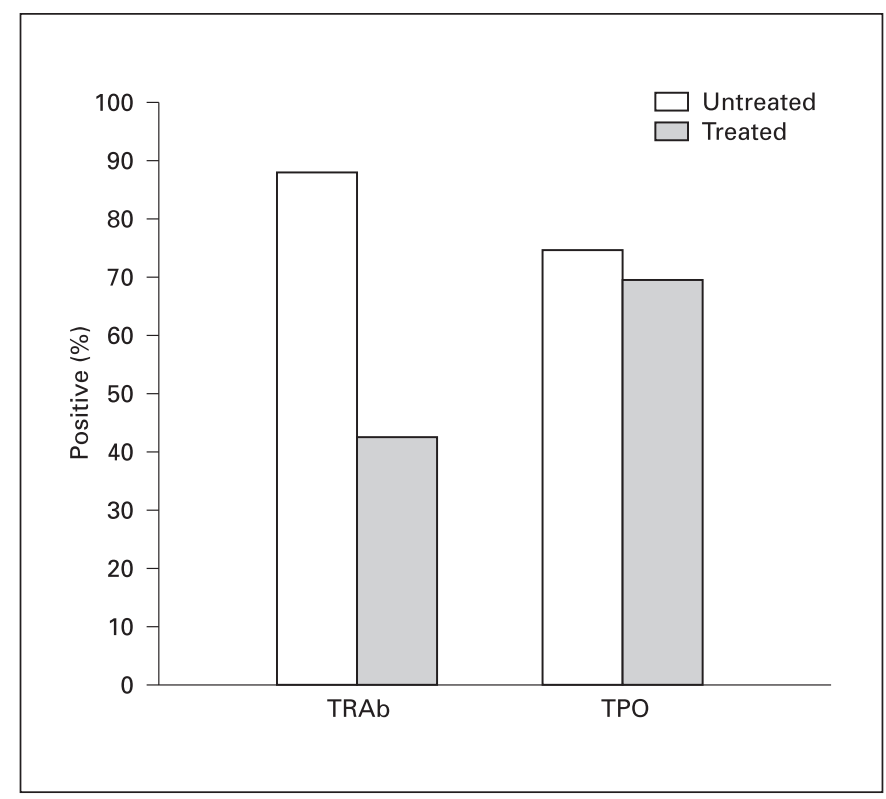

Fig. 2. Comparison between treated and untreated groups of Omani patients with GD who are positive for TRAb and TPO antibodies.

\section{Discussion}

TRAb is a well-known marker of thyroid gland autoimmunity. It has been reported to be the direct cause of hyperthyroidism in GD patients and one of the best examples of pathogenic autoantibodies [4]. The level of TRAb is measured routinely to confirm the diagnosis of GD and many authors have reported high levels of TRAb in GD patients [6, 8-10] similar to our results.

Earlier investigations had suggested that TRAb levels tend to fall during antithyroid drug treatment, which may have some predictive and prognostic value in the recurrence of GD after treatment $[5,11,12]$. Our study has confirmed this observation as evidenced by the significantly lower TRAb level in treated patients as compared to the untreated group. The post-treatment decline in TRAb levels may indicate that the patient's thyrotoxicosis is of an autoimmune etiology rather than due to other causes.

Our study showed no statistical differences in TPO levels in the treated and untreated GD patients. An earlier report had shown an increase in serum levels of TPO after treating patients with ${ }^{131} \mathrm{I}$ [13] while another showed a decrease [14]. These variations may be due to differences in the immunological response caused by a decline in disease activity or a direct effect of the drug.
Of most interest, in the current study, is the absence of a statistically positive correlation between the levels of TRAb and TPO autoantibodies in GD patients, which is not consistent with a previous study [15] that had reported such a correlation. The differences in the two studies may be due to the nature of GD pathogenesis [16], to the number of subjects studied or different assays used as well as genetic and environmental factors. Patients with SLE in this study, representing a nonthyroid autoimmune disease, had higher levels of TRAb and TPO antibody than normal subjects, similar to other studies $[17,18]$.

The level of TRAb and anti-TPO among the general population in Oman is not known. Our findings have shown that the corresponding values are 2 and $6 \%$ in 50 normal subjects. This number is too small to draw any conclusion such as prevalence rates. However, the estimated prevalence of TPO antibodies among the general population in other studies has been shown to be as high as $15 \%[15,19]$ and rises with age [20].

\section{Conclusion}

This study shows high levels of TRAb in Omani patients with active GD and a lower, but significant, level in patients treated with ${ }^{131}$ I. Similarly, the level of TPO antibodies was high in GD patients, though it did not correlate with that of TRAb.

\section{Acknowledgments}

We would like to thank Miss Amna Al-Buloshi for her help in the statistical analysis of the data. 


\section{References}

1 Rees Smith B, McLachlan SM, Furmaniak J: Autoantibodies to the thyrotropin receptor. Endocr Rev 1988;9:106-121.

2 Marcocci C, Chiovato L: Thyroid-directed antibodies; in Braverman LE, Utiger R (eds): Werner and Ingbar's The Thyroid. Philadelphia, Lippincott, 2000, p 414.

$\checkmark 3$ Tonacchera M, Van Sande J, Parma J, Duprez L, Cetani F, Costagliola S, Dumont JE, Vassart G: TSH receptor and disease. Clin Endocrinol (Oxf) 1996;44:621-633.

$\checkmark 4$ Rapoport B, Chazenbalk GD, Jaume JC, McLachlan SM: The thyrotropin receptor: Interaction with thyrotropin and autoantibodies. Endocr Rev 1998;19:673-716.

5 Arqueros MC, el Tamer E, el Tamer S, Houssay $\mathrm{AB}$ : TSH receptor antibodies as a recurrence index of Graves' disease treated with antithyroid drugs. Medicina (B Aires) 1991;51: 9-13.

6 Bech K: Immunological aspects of Graves' disease and importance of thyroid stimulating immunoglobulins; thesis. Acta Endocrinol (Copenh) 1983;254(suppl):1-35.

7 McLachlan SM, Rapoport B: The molecular biology of thyroid peroxidase: Cloning, expression and role as autoantigen in autoimmune thyroid disease. Endocr Rev 1992;13:192206.

$>8$ Gauna A, Segura G, Sartorio G, Soto R, SegalEiras A: Immunological aspects of Graves' disease patients in different clinical stages. J Endocrinol Invest 1989; 12:671-677.
>9 Kawai K, Tamai H, Matsubayashi S, Mukuta T, Morita T, Kubo C, Kuma K: A study of untreated Graves' patients with undetectable TSH binding inhibitor immunoglobulins and the effect of anti-thyroid drugs. Clin Endocrinol (Oxf) 1995; 43:551-556.

10 Sergio MR, Godinho C, Guerra L, Agapito A, Fonseca F, Costa C: TSH anti-receptor antibodies in Graves' disease. Acta Med Port 1996; 9:229-231.

11 Wilson R, Fraser WD, McKillop JH, Thompson JA: The prognostic value of TSH receptor binding and thyroid stimulating antibodies following antithyroid drug treatment of Graves' disease. Acta Endocrinol (Copenh) 1989;121: 666-670.

12 Feldt-Rasmussen U, Schleusenter H, Carayon P: Meta-analysis evaluation of the impact of thyrotropin receptor antibodies on long term remission after medical therapy of Graves' disease. J Clin Endocrinol Metab 1994;78:98102.

13 Feldt-Rasmussen U, Bech K, Date J, Petersen PH, Johansen K, Madsen SN: Thyroid stimulating antibodies, thyroglobulin antibodies and serum proteins during antithyroid treatment with radioiodine or propylthiouracil of Graves' disease. Allergy 1982;32:161-172.

14 Takamatsu J, Hosoya T, Kohno Y, Naito N, Sakeda K, Kuma K, Ohsawa N: Changes in serum autoantibodies to thyroid peroxidase during antithyroid drug therapy for Graves' disease. Endocrinol Jpn 1990;37:275-283.
15 Corapcioglu D, Yelmaz A, Tonyukuk V, Bastemir M, Emral R, Gullu S, Uysal A, Kamel N, Erdogan G: Thyrotropin receptor antibody levels in patients with autoimmune thyroid disease in iodine deficient areas. Turkish J Endocrinol Metabol 2000;4:119-122.

16 Jaume JC, Kakinuma A, Chazenbalk GD, Rapoport B, Mc Lachlan SM: Thyrotropin receptor autoantibodies in serum are present at much lower levels than thyroid peroxidase autoantibodies: Analysis by flow cytometry. J Clin Endocrinol Metab 1997;82:500-507.

17 Vianna JL, Haga HJ, Asherson RA, Swana G, Hughes GR: A prospective evaluation of antithyroid antibody prevalence in 100 patients with systemic lupus erythematosus. J Rheumatol 1991;18:1193-1195.

18 Pyne D, Isenberg DA: Autoimmune thyroid disease in systemic lupus erythematosus. Ann Rheum Dis 2002;6:70-72.

19 Beever K, Bradbury J, Phillips D, McLachlan SM, Pegg C, Goral A, Overbeck W, Feifel G, Smith BR: Highly sensitive assays of autoantibodies to thyroglobulin and to thyroid peroxidase. Clin Chem 1989;35:1949-1954.

20 Mariotti S, Sansoni P, Barbesino G, Caturegli P, Monti D, Cossarizza A, Giacomelli T, Passeri G, Fagiolo U, Pinchera A, Franceschi C: Thyroid and other organ-specific autoantibodies in healthy centenarians. Lancet 1992;339: 1506-1508. 